\title{
STATUS OF MILK PRODUCTION AND SUBCLINICAL MASTITIS IN DAIRY COWS ALONG WITH SOCIOECONOMIC CONDITION OF THE FARMERS
}

\author{
M. M. Hasan, S. Talukder, M. A. Maghla, K. N. Shithi, S. Akter, N. Hasan, M. A. Islam, M. A. Islam, M. \\ R. Alam, M. N. Mia, S. N. Trisha, R. A. Lima, S. Rana, M. Kamruzzaman, M. S. Hossain, B. H. Mehedi, \\ H. A. Rifat, M. A. Ehsan and M. T. Islam*
}

Department of Medicine, Faculty of Veterinary Science, Bangladesh Agricultural University, Mymensingh-2202, Bangladesh

\begin{abstract}
A cross sectional study was conducted to characterize the present situation of milk production, to identify the existing socioeconomic status of dairy farmers, and to determine the prevalence of subclinical mastitis (SCM) in dairy cows. A total of 229 smallholder dairy farms in the surrounding areas of Bangladesh Agricultural University were investigated during January to March 2015. Direct interview with farmers, and physical examination of the cows were done to collect farm and cow level data. It appeared that all of the farmers were involved in other occupations besides dairying, in which almost half of them $(48.29 \%)$ belong to agricultural cultivation. Educational level of the most of the farmers was illiterate to primary level (68.5\%). The average annual income of farm owners was Tk. 219109.17, of which around half of the total income comes from livestock. Average milk production of the farms was $7.73 \mathrm{~L} /$ day with a range of 0.5 to $305 \mathrm{~L}$. Milk samples were collected from randomly selected 101 milking cows and were subjected to somatic cell count (SCC) by automatic nucleocounter machine. The overall prevalence of subclinical mastitis was $20.79 \%$. The prevalence of subclinical mastitis was comparatively higher in Sahiwal cows (42.86\%), cows that yield $>5$ to $10 \mathrm{~L}$ milk per day, and in late lactation stage (>180 days).
\end{abstract}

Keywords: Subclinical mastitis, somatic cell count, prevalence, dairy, socioeconomic status

\section{INTRODUCTION}

Agricultural economy of Bangladesh largely depends on livestock. Livestock contributes about 1.66 percent to national GDP (Gross Domestic Product) and shares 14.21 percent of agricultural GDP in 2015-16 (DLS, 2016). The smallholder dairy, through its economic contributions shares $18.6 \%$ of the animal farming GDP. Farmers get more than $50 \%$ of their annual income through dairy farming irrespective of their gender or land ownership, and on average milk of $0.85 \mathrm{~L} /$ day are available for a family that keeps dairy stock (FAO, 2013). The milk production in Bangladesh is 72.75 lakh metric ton whereas the demand is 146.91 lakh metric ton and deficiency is 74.16 lakh metric ton (DLS, 2016). Several disease problems occur in dairy animals which impede its milk production (Shamsuddoha et al., 2000). Among these, mastitis is one of the most important diseases hampering the growth of the dairy sector by causing huge economic loss in dairy animals because of lower milk production, milk withdrawal following treatment, high treatment costs, labor, premature culling and death (Miller et al., 1993).

Mastitis is a multi-etiological and complex disease, which is defined as inflammation of parenchyma of mammary glands. It is characterized by physical, chemical and usually bacteriological changes in milk, and pathological changes in glandular tissues (Radostits et al., 2000). Major mastitis causing organisms are Staphylococci spp., Streptococci spp. and other gram-negative bacteria (Mubarack et al., 2012). It is mainly categorized into clinical mastitis (CM) and subclinical mastitis (SCM). The signs of CM are inflammation of the udder and changes in milk (Kader et al., 2003). In SCM, there are no visible abnormalities in the udder tissues and milk except an elevated somatic cell count (SCC) (MacDougall et al., 2001). Subclinical mastitis is 15 to 40 times more prevalent than clinical mastitis and causes high economic losses in most dairy herds, and responsible for much greater loss to the dairy industry in Bangladesh (Kader et al., 2003). Tripura et al. (2014) reported that the overall prevalence of SCM in lactating cows was 51.8\% and 51.4\% at Mymensingh sadar while Sarker et al. (2013) recorded $20.2 \%$ prevalence in the same region. The identified risk factors that influence the occurrence of SCM are age, parity, lactation stage, milk yield, breed, previous mastitis record, floor type, disinfection of fingers, teat dipping, etc (Doherr et al., 2007; Karimuribo et al., 2008; Madut et al., 2009; Sarker et al., 2013).

*Corresponding e-mail address: taohid@bau.edu.bd 


\section{Hasan and others}

For the diagnosis of SCM, various methods based on physical and chemical changes of milk are used (Batra and Mcallister, 1984; Emanuelson et al., 1987). Among them, California mastitis test (CMT), and milk somatic cell count (SCC) are the effective indirect and direct screening tests, respectively (Sarker et al., 2013). SCC is a useful evocator of intramammary infection as well as an important component of milk quality assessment, hygiene and mastitis control. However, there is a huge lack of awareness among the dairy farmers about the proper control and management of SCM. Moreover, insufficient information is available about the prevalence of SCM and association of potential risk factors in dairy cows of Mymensingh area. In Mymensingh district, small and large scale dairy farms have been raising constantly. Especially, small income group of people has taken dairying as commercial enterprise. It is needful to know details about the performances of dairy breeds and management practices as well as the socioeconomic status of the dairy farmers to settle a future plan for dairy development in this region. Hence the study was conducted (i) to identify the present status of milk production along with the management aspects of small scale dairy farmers in surrounding areas of Bangladesh Agricultural University, (ii) to investigate the socioeconomic status of dairy farmers in that area, and (iii) to estimate the prevalence, and to find out the risk factors of subclinical mastitis in dairy cows of that area.

\section{MATERIALS AND METHODS}

\section{Study area, animals and management}

A cross sectional study was carried out during the period of January to March of 2015 at Mymensingh district, the north-east part of Bangladesh; which is located at longitude $90.45^{\circ} \mathrm{E}$, latitude $24.70^{\circ} \mathrm{N}$ and altitude $15.52 \mathrm{~m}$. In this study a total of 229 household dairy farmers having 365 milch cows were selected by random sampling from 9 villages. The dairy cattle were kept under different housing and management practices in the rural areas selected in, and surroundings of Bangladesh Agricultural University area. In this region, dairy cattle are mainly reared for milk and economic purpose.

\section{Data collection}

A semi structured questionnaire was developed to gather information on dairy management approaches and socioeconomic condition of dairy farmers at the selected areas. During the study, information about different variables (i.e. age, breed, lactation stage and milk yield) from individual animal was recorded by a questionnaire through farmers interview. The data were collected by Magpi android data collection application (Version-5.4.1) with Global Positioning System (GPS).

\section{Sample collection}

From the data of 365 lactating cows, 101 were selected randomly for subclinical mastitis test. The tip of a teat was mopped several times with sterile gauge soaked in $70 \%$ alcohol and allowed to dry. A few streams of foremilk were discarded and 5-10 ml of milk sample from each cow was collected aseptically in sterilized screwcapped test tubes with tag. Milk samples were transported to the laboratory of the Department of Medicine, Bangladesh Agricultural University in ice boxes (approximately $4{ }^{\circ} \mathrm{C}$ ) and preserved at $4{ }^{\circ} \mathrm{C}$ until further laboratory analysis (usually within 24 hours of collection). The milk samples were prepared for somatic cell count according to the procedure described by Sumon et al. (2017) on the next day of sampling.

\section{Detection of subclinical mastitis}

In a study, it was appeared that SCC was the most reliable test and closest to the bacteriological results (Badiuzzaman et al., 2015). So this study used SCC technique to test subclinical mastitis. The SCC (cells/ml) for the milk samples was determined using Nucleo Counter SCC-100 (Coulter electronic-Chemometec A/s, Denmark) following the protocol of Saleh and Faye (2011). In brief, mixing of the representative cell sample (milk) was done with equal volume $(50 \mu 1)$ of lysis buffer. The Nucleo Cassette was loaded with the lysate solution after 30 seconds vortexing and then placed in the instrument, then pressed the "Run" key. After 30 seconds, the cell count was presented on the instrument display. The cows had SCC $>200 \times 10^{3} / \mathrm{ml} \mathrm{were}^{2}$ considered as SCM positive. 


\section{Data Analysis}

The data were extracted from Magpi server as MS Access file. Data analysis was carried out using Epi Info ${ }^{\mathrm{TM}}$ (Epi Info ${ }^{\mathrm{TM}}$ is a trademark of the Centers for Disease Control and Prevention (CDC) used version 7.1.5.2) to generate descriptive statistics (frequencies/proportions) related to the farmer's education, occupation, annual income, dairy management, milk production status, treatment, disease prevalence, etc.

\section{RESULTS AND DISCUSSION}

\section{Social attributes of farmers}

The social status of the dairy farmers has been recorded at the time of investigation and presented in Table 1 . It is observed that, almost half of the farmers (48.29\%) involved in agricultural farming and additionally reared dairy cattle in small scale, and the rest were businessmen, labor, govt. employee, teacher and others (boatman, bricklayer, potter, tailor, shopkeeper and driver) and their proportion were $16.24 \%, 14.53 \%, 11.11 \%, 0.43 \%$ and $9.40 \%$ respectively. Farmers were further categorized based on their academic qualification in which $35.4 \%$ farmers had no formal education and of the rest farmers the percentage of primary level, secondary level, higher secondary level, diploma, degree and honors were $33.1 \%, 18.8 \%, 7.9 \%, 1.7 \%, 0.9 \%$ and 2.2 respectively. Previous researchers reported that 58-60\% farmers were engaged in agriculture with livestock rearing (Siddiki et al., 2015; Varaprasad et al., 2013) and 57\% of the farmers had business as their principal occupation (Khan et al., 2010). Other studies found that $45 \%$ farmers were not educated (Siddiki et al., 2015), but 17.62\% (Hossain et al., 2012) and 76\% (Kabir, 1995) had primary level education. However, other studies revealed that nobody was found illiterate and $60 \%$ of the farmers had higher secondary level education (Khan et al., 2010). These statistics may have been different because of geographical location and education facilities of the studied area.

The annual average household income was estimated to be Tk. 219100 of which, contribution of livestock was $50.53 \%$ whereas another study found only $17.59 \%$ from their livestock (Hossain et al., 2012). The contribution of livestock to total household income for agricultural farmers, businessmen, labors, govt. employees, teachers and other farmers were $63.57 \%, 46.46 \%, 36.49 \%, 37 \%, 50 \%$ and $18.5 \%$, and their annual gross average income were Tk. 218690, Tk. 325320, Tk. 133230, Tk. 232230, Tk. 120000 and Tk. 159450 respectively which expressed that agricultural farmers got maximum income from their dairy. A study reported that maximum farmers were belonged to medium income (Tk. one to four lac) categories (Amin et al., 2015) that reveled to our finding.

Table 1. General information of small household dairy cattle farmers

\begin{tabular}{|c|c|c|c|c|c|c|}
\hline \multicolumn{7}{|l|}{ Occupational status } \\
\hline \multirow[t]{2}{*}{ Occupation } & \multirow[t]{2}{*}{$(\%)$} & \multicolumn{2}{|c|}{$\begin{array}{l}\text { Annual income ('000 } \\
\text { Tk.) }\end{array}$} & \multicolumn{3}{|c|}{$\begin{array}{c}\text { Annual income from livestock ('000 } \\
\text { Tk.) }\end{array}$} \\
\hline & & Total & Average & Total & Average & $\%$ \\
\hline Farmer (Agril.) $(\mathrm{n}=108)$ & 48.29 & 23618 & 218.69 & 15015 & 139.02 & 63.57 \\
\hline Businessman $(n=38)$ & 16.24 & 12362 & 325.32 & 5743 & 151.13 & 46.46 \\
\hline Labour $(\mathrm{n}=34)$ & 14.53 & 4530 & 133.23 & 1653 & 48.62 & 36.49 \\
\hline Govt. employee $(n=26)$ & 11.11 & 6038 & 232.23 & 2234 & 85.92 & 37.00 \\
\hline Teacher $(\mathrm{n}=1)$ & 0.43 & 120 & 120.00 & 60 & 60.00 & 50.00 \\
\hline Others $(n=22)$ & 9.40 & 3508 & 159.45 & 649 & 29.50 & 18.50 \\
\hline Overall $(n=229)$ & & 50176 & 219.10 & 25354 & 110.71 & 50.53 \\
\hline \multicolumn{7}{|l|}{ Educational status } \\
\hline Qualification & & \multicolumn{2}{|c|}{ No. of farmers } & \multicolumn{3}{|c|}{$\%$} \\
\hline No formal education & & \multicolumn{2}{|c|}{81} & \multicolumn{3}{|c|}{35.4} \\
\hline Primary & & \multicolumn{2}{|c|}{76} & \multicolumn{3}{|c|}{33.1} \\
\hline Secondary & & \multicolumn{2}{|c|}{43} & \multicolumn{3}{|c|}{18.8} \\
\hline Higher secondary & & \multicolumn{2}{|c|}{18} & \multicolumn{3}{|c|}{7.9} \\
\hline Diploma & & \multicolumn{2}{|c|}{4} & \multicolumn{3}{|c|}{1.7} \\
\hline Degree & & \multicolumn{2}{|c|}{2} & \multicolumn{3}{|c|}{0.9} \\
\hline Honours & & \multicolumn{2}{|c|}{5} & \multicolumn{3}{|c|}{2.2} \\
\hline
\end{tabular}




\section{Hasan and others}

\section{Overall farm management system}

The study found that all farmers milked their cows manually and they cleaned their cattle house regularly except only one farmer. Majority of the farmers complained that poor availability of feeds and fodders was the principle problem in the area. That's why more than half of the respondents $(56.8 \%)$ were found supplying a combination of concentrate (rice polish, wheat bran, broken rice, rice gruel, oil cake, til oil cake, mustard oil cake), grass and rice straw to their cattle, and $28.8 \%$ farmers added feed additive to increase milk production, though $57.64 \%$ farmers grazed their cattle in field. From Table 2, it is revealed that 53.3\% farmers kept their cattle in concrete floor and the rest kept in soiled. Among them, 27.9\% farmers used no bedding materials and majority $(57.3 \%)$ used straw as bedding. However, gunny bag, saw-dust and ash also were used for bedding. All of the dairy farmers bath their cows at least once in a weak, and the cows were milked once a day in case of $79.5 \%$ farmers. The survey found that only 3 farmers who had no idea about colostrum feeding to calf, and only 6 farmers faced dystocia during the study time and at one year before. In the study area, artificial insemination was practiced by $83.4 \%$ of dairy farmers, but only $46.3 \%$ farmers met with Veterinary Surgeon for treatment purpose. About $21.8 \%$ of the farmers did vaccination against important diseases such Anthrax, Hemorrhagic Septicemia, Black Quarter, Tetanus, FMD and Rabies to keep the cattle free from disease outbreak. Overall management system of the farmers studied in this research is fully supported by (Khan et al., 2010). Farming management is important because, higher prevalence of SCM is associated with dirty floor condition, cows bathed by pouring water, dirty udder and overall poor hygienic management which was reported by Islam et al. (2011). In our experiment, farms having earthen floor had considerably higher risks of subclinical mastitis than cows reared on concrete floor that corresponds with Kayesh et al. (2014).

Table 2. Overall management system in the selected small holder dairy farms

\begin{tabular}{|c|c|c|c|c|c|}
\hline Parameter & Farmer (n) & $(\%)$ & Parameter & Farmer (n) & $(\%)$ \\
\hline Feeding & & & Milking frequency & & \\
\hline Concentrate & 01 & 0.4 & Once daily & 182 & 79.5 \\
\hline Grass & 03 & 1.3 & Twice daily & 47 & 20.5 \\
\hline Straw & 06 & 2.6 & Colostrum feeding & & \\
\hline Concentrate + Grass & 01 & 0.4 & Yes & 226 & 98.7 \\
\hline Concentrate + Straw & 48 & 21.0 & No & 3 & 1.3 \\
\hline Grass + Straw & 40 & 17.5 & Floor Type & & \\
\hline Concentrate + Grass + Straw & 130 & 56.8 & Soiled & 107 & 46.7 \\
\hline Bedding materials & & & Concrete & 122 & 53.3 \\
\hline Gunny bag & 21 & 9.2 & Feed additive & & \\
\hline Saw-dust & 01 & 0.4 & Yes & 66 & 28.8 \\
\hline Straw & 131 & 57.3 & No & 163 & 71.2 \\
\hline Saw-dust + straw & 06 & 2.7 & Grazing & & \\
\hline Gunny bag + Straw & 03 & 1.3 & Yes & 132 & 57.6 \\
\hline Ash + gunny bag & 01 & 0.4 & No & 97 & 42.4 \\
\hline Ash + straw & 01 & 0.4 & Dystocia & & \\
\hline Ash + gunny bag + Straw & 01 & 0.4 & Farmer faced & 6 & 2.6 \\
\hline No material & 64 & 27.9 & Farmer didn't face & 223 & 97.4 \\
\hline Bathing frequency (weekly) & & & Service provided & & \\
\hline Once & 163 & 71.2 & Natural & 38 & 16.6 \\
\hline Twice & 27 & 11.8 & Artificial & 191 & 83.4 \\
\hline Thrice & 08 & 3.5 & Vaccination & & \\
\hline 4 Times & 05 & 2.2 & Yes & 50 & 21.8 \\
\hline 5 Times & 03 & 1.3 & No & 179 & 78.2 \\
\hline 6 Times & 00 & 0.0 & Farmers go for treatment & & \\
\hline \multirow[t]{2}{*}{7 Times } & 23 & 10 & Chemist & 01 & 0.4 \\
\hline & & & Quack & 100 & 43.7 \\
\hline Shed cleaning (daily) & & & Veterinary Surgeon(VS) & 106 & 46.3 \\
\hline Once (regular) & 167 & 72.9 & Himself & 03 & 1.3 \\
\hline Twice (regular) & 43 & 18.7 & Quack + VS & 15 & 6.5 \\
\hline Thrice (regular) & 18 & 7.8 & Himself + VS & 02 & 0.9 \\
\hline Irregular & 1 & 0.4 & Chemist + Quack & 02 & 0.9 \\
\hline
\end{tabular}




\section{Milk production status}

Demographic information of cattle population with milk status in the selected area are reported in Table-3. Total number of 1060 cattle population were found in the area at study period including calves (35.6\%) followed by lactating cows $(34.4 \%)$, dry cows $(13.6 \%)$, heifers $(10.9 \%)$ and bulls $(5.2 \%)$. Cow milk production of BAU surrounding area was about $1770.75 \mathrm{~L} /$ day and average milk production of a household was $7.73 \mathrm{~L} /$ day, of which $88.85 \%$ of total milk were sold to local market at a price of about Tk. 50 per litre and daily total income of the farmers from selling milk was Tk. 81405. Most of the farmers $(72.92 \%)$ have been used to both selling and consuming milk. Some farmers $(14.41 \%)$ were rearing dairy cattle only to sell their milk and some $(12.67 \%)$ only for consuming, and almost all of the farmers (94.3\%) wanted to continue their small dairy farming. However, the average milk yield of SCM positive cows was $3.7 \mathrm{~L}$ while $3.8 \mathrm{~L}$ was in negative cows, which is in agreement with the findings of Sarker et al. (2013).

Table 3. Information of cattle and milk status in selected area

\begin{tabular}{|c|c|c|c|c|c|}
\hline \multicolumn{6}{|c|}{ Distribution of cattle in selected area $(n=1060)$} \\
\hline & Lactating cow & Dry cow & Calf & Heifer & Bull \\
\hline $\mathrm{n}$ & 365 & 144 & 380 & 116 & 55 \\
\hline$\%$ & 34.4 & 13.6 & 35.9 & 10.9 & 5.2 \\
\hline \multicolumn{6}{|c|}{ Milk production Status } \\
\hline & $\begin{array}{l}\text { Milk yield } \\
\text { (L/day) }\end{array}$ & $\begin{array}{l}\text { Milk selling } \\
\text { (L/day) }\end{array}$ & $\begin{array}{l}\text { Milk consumed } \\
\text { (L/day) }\end{array}$ & \multicolumn{2}{|c|}{$\begin{array}{l}\text { Income from selling milk } \\
\text { daily (Tk.) }\end{array}$} \\
\hline Maximum & 305 & 300 & 5 & \multicolumn{2}{|c|}{15000} \\
\hline Minimum & 0.5 & 0 & 0 & \multicolumn{2}{|c|}{0} \\
\hline Average & 7.73 & 6.87 & 0.86 & \multicolumn{2}{|c|}{355.48} \\
\hline Total & 1770.75 & 1573.25 & 197.5 & \multicolumn{2}{|c|}{81405} \\
\hline \multicolumn{6}{|c|}{ Utilization of milk } \\
\hline & Milk sell only & $\begin{array}{l}\text { Milk consume } \\
\text { only }\end{array}$ & $\begin{array}{c}\text { Both sell \& } \\
\text { consume milk }\end{array}$ & \multicolumn{2}{|c|}{ Continue dairy farming } \\
\hline Farmer (n) & 33 & 29 & 167 & \multicolumn{2}{|c|}{216} \\
\hline$\%$ & 14.41 & 12.67 & 72.92 & \multicolumn{2}{|c|}{94.3} \\
\hline
\end{tabular}

\section{Overall prevalence of SCM}

Regarding SCC, results of subclinical mastitis are shown in Table-4. The association in prevalence of SCM in relation to difference among age, breed, amount of milk production and lactating stage was not significant $(\mathrm{P}>0.05)$ in our study. It appears from Table-4, the overall prevalence of subclinical mastitis was $20.79 \%$ in lactating cows which is strongly supported by the result of $19.9 \%, 20.2 \%$ and $21.9 \%$ overall prevalence of subclinical mastitis in lactating dairy cows which are reported respectively by Rahman et al. (2009), Sarker et al. (2013) and Qayyum et al. (2016). Lower prevalence that 16.3\% was also reported in smallholder dairy farms of Zimbabwe (Katsande et al., 2013). Other studies reported the overall prevalence was in range of $27.5 \%$ to $55 \%$ (Barua et al., 2014; Kayesh et al., 2014; Islam et al., 2010; Islam et al., 2011; Kathiriya et al., 2014; Rabbani et al., 2010; Ayano et al., 2013; Rahman et al., 2010; Siddiquee et al., 2013; Tripura et al., 2014; Shrestha et al., 2012; Sanotharan et al., 2016). On the basis of SCC the result of the study is not in conformity with the earlier findings of Badiuzzaman et al. (2015) and Östensson et al. (2013) who reported the prevalence of SCM was $66.67 \%, 71.9 \%$ and $88.6 \%$ respectively. These prevalence rates of SCM might be different due to geographical locations, difference of breeds of animals, management practices and the tests used for screening of the milk samples (Rabbani et al., 2010; Barua et al., 2014). 
Hasan and others

Table 4. Distribution of SCM in lactating cows in relation to different variables

\begin{tabular}{|c|c|c|c|c|c|}
\hline Variables & $\begin{array}{c}\text { No. of cows } \\
\text { tested }\end{array}$ & $\begin{array}{c}\text { No. of positive } \\
\text { cows }\end{array}$ & $\begin{array}{c}\text { Prevalence } \\
(\%)\end{array}$ & OR $(95 \%$ CI $)$ & P-value \\
\hline \multicolumn{6}{|l|}{ Age (year) } \\
\hline $3-5$ & 47 & 10 & 21.28 & Reference & - \\
\hline$>5-10$ & 48 & 11 & 22.92 & $1.1(0.42-2.90)$ & 0.847 \\
\hline$>10$ & 6 & 0 & - & - & - \\
\hline \multicolumn{6}{|l|}{ Breed } \\
\hline Holstein Friesian & 26 & 6 & 23.07 & $1.7(0.37-7.84)$ & 0.493 \\
\hline Jersey & 2 & 0 & - & - & - \\
\hline Sahiwal & 7 & 3 & 42.86 & $4.25(0.61-29.45)$ & 0.127 \\
\hline Cross & 20 & 3 & 15.00 & Reference & - \\
\hline Indigenous & 46 & 9 & 19.57 & $1.38(0.33-5.74)$ & 0.658 \\
\hline \multicolumn{6}{|l|}{ Milk Yield (Litre) } \\
\hline$<3$ & 59 & 12 & 20.34 & $1.79(0.20-15.95)$ & 0.598 \\
\hline $3-5$ & 23 & 5 & 21.74 & $1.94(0.19-19.74)$ & 0.568 \\
\hline$>5-10$ & 11 & 3 & 27.27 & $2.62(0.22-31.35)$ & 0.435 \\
\hline$>10$ & 8 & 1 & 12.50 & Reference & - \\
\hline \multicolumn{6}{|l|}{ Lactating stage (days) } \\
\hline 0 to 60 & 30 & 4 & 13.33 & Reference & - \\
\hline$>60$ to 120 & 21 & 3 & 14.28 & $1.08(0.21-5.43)$ & 0.922 \\
\hline$>120$ to 180 & 19 & 5 & 26.31 & $2.32(0.53-10.06)$ & 0.252 \\
\hline$>180$ & 31 & 9 & 29.03 & $2.66(0.72-9.83)$ & 0.134 \\
\hline Overall & 101 & 21 & 20.79 & & \\
\hline
\end{tabular}

\section{Prevalence of SCM in different ages}

In this study, $21.28 \%$ cows of 3 to 5 years of age were positive to SCM test. This result corroborates with previous researches where $22.9 \%, 22.22 \%$ and $22.22 \%$ was reported as the prevalence of SCM in up to 5 years of aged cows (Siddiquee et al., 2013; Islam et al., 2011 and Kathiriya et al., 2014). But at the same time, these findings are contradictory to our result because of almost same prevalence $(22.92 \%)$ were recorded in cows between $>5$ to 10 years of age. However, several studies published earlier which reported the prevalence of SCM was increased with the advancement of age of cows (Islam et al., 2010; Sarker et al., 2013; Kayesh et al., 2014 and Tripura et al., 2014).

\section{Prevalence of SCM in different breeds}

It is observed from Table-4 that Sahiwal breeds were more vulnerable for SCM than the other breeds, and 23.07\%, 15.00\% and 19.57\% prevalence were recorded in Holstein Friesian, Indigenous cross and Indigenous breed respectfully. Though highest prevalence (42.86\%) was reported in Sahiwal breed the association of breed with SCM was non-significant in our study. Several studies were in agreement with this findings in past (Barua et al., 2014; Islam et al., 2010). Indigenous cows had prevalence of $19.57 \%$ in our study which was supported by other findings which reported 22.45\% and 24.6\% prevalence in local breed in Bangladesh (Kayesh et al., 2014; Islam et al., 2011). On the other hand, this study reported cross breed cows having $15 \%$ prevalence of SCM, but another study found $88.7 \%$ prevalence in cross breed (Sarker et al., 2013) which is controversial.

\section{Prevalence of SCM on the basis of milk production}

The highest prevalence of subclinical mastitis based on daily milk yield was $27.27 \%$ that found in the cows produced milk within a range of $>5$ to $10 \mathrm{~L}$ daily, followed by less than $3 \mathrm{~L}(20.34 \%), 3$ to $5 \mathrm{~L}(21.74 \%)$ and more than $10 \mathrm{~L}(12.50 \%)$. In the study, the prevalence of SCM was increased with higher milk production but lowest prevalence $(12.50 \%)$ found in cows milked more than $10 \mathrm{~L}$ of milk which is consistent with the finding of 14.29\% SCM (Rabbani et al., 2010). Nevertheless, the results contradict to another study which revealed that the prevalence of SCM was significantly $(\mathrm{p}<0.05)$ higher $(37.12 \%)$ in high $(>10 \mathrm{~L})$ yielding cows than low to medium yielders (Islam et al., 2010). 


\section{Prevalence of SCM at different stages of lactation}

It appears from the Table- 4 that all the stages of lactation in dairy animals affected with SCM. The prevalence of SCM was recorded as $13.33 \%, 14.28 \%, 26.31 \%$ and $29.03 \%$ during the stages of $<60$ days, $>60$ to 120 days, $>120$ to 180 days and >180 days of lactation respectively. The highest prevalence $(29.03 \%)$ of SCM was recorded during late lactation (>180 days) stage in dairy cows than early and mid-lactation which is in conformity with the earlier findings in which maximum prevalence $(68.75 \%)$ was reported in last lactation stage in Holstein Friesian Cross cows (Rabbani et al., 2010). The prevalence of SCM could be high at late stage of lactation due to long exposure time (Rabbani et al., 2010) and followed with relaxed teat sphincters (Qayyum et al., 2016). However, these results are contradicted that the highest prevalence $(76.47 \%)$ of SCM was found at early lactation stage by SCC and lowest in mid and late lactation (Badiuzzaman et al., 2015; Kayesh et al., 2014; Ayano et al., 2013)).

In conclusion, this study showed that the overall prevalence of subclinical mastitis was $20.79 \%$ in lactating cows and their breeds, level of milk yield and stages of lactation are the important host factors associated with the prevalence of SCM in cows. Considering all the studied parameters, it can be concluded that dairy farming is a profitable practice that may improve socioeconomic status. Hence, this study suggests that proper operation should be directed to develop management practices as well as awareness of SCM among the dairy farmers with a view to increase milk production.

\section{REFERENCES}

1. Amin MR, Siddiki MA, Kabir AKMA, Faruque MO and Khandaker ZH (2015). Status of buffalo farmers and buffaloes at Subornochar upozila of Noakhali district in Bangladesh. Progressive Agriculture 26: 71-78.

2. Ayano AA, Hiriko F, Simyalew AM and Yohannes A (2013). Prevalence of subclinical mastitis in lactating cows in selected commercial dairy farms of Holeta district. Journal of Veterinary Medicine and Animal Health 5:67-72.

3. Badiuzzaman M, Samad MA, Siddiki SHMF, Islam MT and Saha S (2015). Subclinical mastitis in lactating cows: Comparison of four screening tests and effect of animal factors on its occurrence. Bangladesh Journal of Veterinary Medicine 13:41-50.

4. Barua M, Prodhan MAM, Islam K, Chowdhury S, Hasanuzzaman M, Imtiaz MA and Das GB (2014). Subclinical mastitis prevalent in dairy cows in Chittagong district of Bangladesh: Detection by different screening tests. Veterinary World 7:483-488.

5. Batra TR, and Mcallister AJ (1984). A comparison of mastitis detection methods in dairy cattle. Canadian Journal of Animal Science 64:305-312.

6. DLS: Livestock aconomy a (2015-2016). http://dls.portal.gov.bd/sites/default/files/files/dls.portal.gov.bd/page/5f7daa39_d71f_4546_aeaf_55b72ee86 8f2/Annual\%20report\%20of\%202015-2016\%20\%20Date\%2010-10-2016.pdf (Accessed on 4 July, 2018)

7. Doherr MG, Roesch M, Schaeren W, Schallibaum M and Blum JW (2007). Risk factors associated with subclinical mastitis in dairy cows on Swiss organic and conventional production system farms. Veterinarni Medicina 52:487-495.

8. Emanuelson U, Olsson T, Holmberg O, Hageltorn M, Mattila T, Nelson L, Astrom G (1987). Comparison of some screening tests for detecting mastitis. Journal of Dairy Science 70:880-886.

9. FAO: Bangladesh National Dairy $\quad$ Profile $\quad$ (2013). http://cdn.aphca.org/dmdocuments/PAP_13_Dairy\%20Profile\%20Bangladesh.pdf (Accessed on 4 July, 2018)

10. Hossain SMJ, Bhuiyan AKFH, Haque KS, Akteruzzaman M, Sarker NR and Sultana N (2012). A socioeconomic study on Red Chittagong Cattle (RCC) farmers in selected upazillas of Chittagong district. Bangladesh Journal of Livestock Research 19:123-136.

11. Islam MA, Islam MZ, Islam MA, Rahman MS and Islam MT (2011). Prevalence of subclinical mastitis in dairy cows in selected areas of Bangladesh Bangladesh. Journal of Veterinary Medicine 9:73-78.

12. Islam MA, Rahman AKMA, Rony SA and Islam MS (2010). Prevalence and risk factors of mastitis in lactating dairy cows at Baghabari milk shed area of Sirajganj. Bangladesh Journal of Veterinary Medicine 8:157-162. 
13. Kabir MA (1995). An economic study of subsidized private dairy farming in selected area of Bangladesh. MS Thesis, Department of Agricultural Economics, Bangladesh Agricultural University, Mymensingh-2202.

14. Kader MA, Samad MA and Saha S (2003). Influence of host level factors on prevalence and economics of sub-clinical mastitis in dairy cows in Bangladesh. Indian Journal of Dairy Science 56:235-240.

15. Karimuribo ED, Fitzpatrick JL, Swai ES, Bell C, Bryant MJ, Ogden NH, Kambarage DM and French NP (2008). Prevalence of subclinical mastitis and associated risk factors in smallholder dairy cows in Tanzania. Veterinary Record 163:16-21.

16. Kathiriya JB, Kabaria BB, Saradava DA and Sanepara DP (2014). Prevalence of subclinical mastitis in dairy cows in Rajkot district of Gujarat. International Journal of Science and Nature 5:433-436.

17. Katsande S, Matope G, Ndengu M and Pfukenyi DM (2013). Prevalence of mastitis in dairy cows from smallholder farms in Zimbabwe. Onderstepoort Journal of Veterinary Research 80:1-7.

18. Kayesh MEH, Talukder M and Anower AKMM (2014). Prevalence of subclinical mastitis and its association with bacteria and risk factors in lactating cows of Barisal district in Bangladesh. International Journal of Biological Research 2:35-38.

19. Khan ABMKI, Baset MA and Fouzder SK (2010). Study on management and production system of small scale dairy farm in a selective rural area of Bangladesh. Journal of Science Foundation 8:13-21.

20. MacDougall S, Murdough P, Pankey W, Delaney C, Barlow J and Scruton D (2001). Relationships among somatic cell count, California mastitis test, impedance and bacteriological status of milk in goats and sheep in early lactation. Small Ruminant Research 40:245-254.

21. Madut NA, Gadir AEA and Jalii IME (2009). Host determinants of bovine mastitis in semi-intensive production system of Khartoum state, Sudan. Journal of Cell and Animal Biology 3:71-77.

22. Miller GY, Bartlett PC, Lance SE, Anderson J and Heider LE (1993). Costs of clinical mastitis and mastitis prevention in dairy herds. Journal of the American Veterinary Medical Association 202:1230-1236.

23. Mubarack HM, Doss A, Vijayasanthi M and Venkataswamy R (2012). Antimicrobial drug susceptibility of Staphylococcus aureus from subclinical bovine mastitis in Coimbatore, Tamilnadu, South India. Veterinary World 5:352-355.

24. Östensson K, Lam V, Sjögren N and Wredle E (2013). Prevalence of subclinical mastitis and isolated udder pathogens in dairy cows in Southern Vietnam. Tropical Animal Health and Production 45:979-986.

25. Qayyum A, Khan JA, Hussain R, Avais M, Ahmed N, Khan A and Khan MS (2016). Prevalence and association of possible risk factors with sub-clinical mastitis in Cholistani cattle. Pakistan Journal of Zoology 48:519-525.

26. Rabbani AFMG and Samad MA (2010). Host determinants based comparative prevalence of subclinical mastitis in lactating Holstein-Friesian cross cows and Red Chittagong cows in Bangladesh. Bangladesh Journal of Veterinary Medicine 8:17-21.

27. Radostits OM, Gay CC, Blood DC and Hinchkliff KW (2000). Veterinary Medicine: A Textbook of the Diseases of Cattle, Sheep, Pigs, Goats and Horses. 9th ed. ELBS \& Baillier Tindall, pp: 563-660.

28. Rahman MA, Bhuiyan MMU, Kamal MM and Shamsuddin M (2009). Prevalence and risk factors of mastitis in dairy cows. Bangladesh Veterinarian 26:54-60.

29. Rahman MM, Islam MR, Uddin MB and Aktaruzzaman MA (2010). Prevalence of subclinical mastitis in dairy cows reared in Sylhet district of Bangladesh. International Journal of Biological Research 1: 23-28.

30. Saleh SK and Faye B (2011). Detection of subclinicalmastitis in dromedary camels (Camelus dromedaries) using somatic cell counts, california mastitis test and udder pathogen. Emirates Journal of Food and Agriculture 23:48-58.

31. Sanotharan N, Pagthinathan M and Nafees MSM (2016). Prevalence of bovine subclinical mastitis and its association with bacteria and risk factors in milking cows of Batticaloa district in Srilanka. International Journal of Scientific Research and Innovative Technology 3:137-150.

32. Sarker SC, Parvin MS, Rahman AKMA and Islam MT (2013). Prevalence and risk factors of subclinical mastitis in lactating dairy cows in north and south regions of Bangladesh. Tropical Animal Health and Production 45:1171-1176.

33. Siddiki MA, Amin MR, Kabir AKMA, Faruque MO and Khandaker ZH (2015). Socio-economic status of buffalo farmers and the performances of buffaloes at Lalpur Upozila of Natore district in Bangladesh. Bangladesh Journal of Animal Science 44:157-165. 
34. Siddiquee NU, Tripura TK, Islam MT, Bhuiyan SA, Rahman AKMA and Bhuiyan AKFH (2013). Prevalence of sub-clinical mastitis in high yielding crossbred cows using Draminski mastitis detector. Bangladesh Journal of Veterinary Medicine 11:37-41.

35. Shamsuddoha AK and Edwards G (2000). Dairy Industry in Bangladesh: Problems and Prospects. AARES 2000 Conference, School of Business, La Trobe University.

36. Shrestha S and Bindari YR (2012). Prevalence of sub-clinical mastitis among dairy cattle in Bhaktapur district, Nepal. International Journal of Agriculture and Biosciences 1:16-19.

37. Sumon SMMR, Ehsan MA and Islam MT (2017). Subclinical mastitis in dairy cows: Somatic cell counts and associated bacteria in Mymensingh, Bangladesh. Bangladesh Journal of Agricultural University 15:266271.

38. Tripura TK, Sarker SC, Roy SK, Parvin MS, Sarker RR, Rahaman AKMA and Islam MT (2014). Prevalence of subclinical mastitis in lactating cows and efficacy of intramammary infusion therapy. Bangladesh Journal of Veterinary Medicine 12:55-61.

39. Varaprasad AR, Raghunandan T, Kumar MK, Prakash MG and Scientist S (2013). Studies on the socio economic profile and constraints by the farmers rearing Jersey X Sahiwal cows in Chittoor district of Andhra pradesh. International Journal of Science, Environment and Technology 2:404-409. 